\title{
Synthesis, Crystal Structure, and Characterization of Ternary Copper(II) Complex Derived from N-(salicylidene)-L-valine
}

\author{
Sundaramurthy Santha Lakshmi ${ }^{1}$ and Kannappan Geetha ${ }^{2}$ \\ ${ }^{1}$ Department of Chemistry, DKM College for Women, Tamil Nadu, Vellore 632 001, India \\ ${ }^{2}$ Department of Chemistry, Muthurangam Government Arts College, Tamil Nadu, Vellore 632 002, India \\ Correspondence should be addressed to Sundaramurthy Santha Lakshmi; santhalakshmi_s@yahoo.com
}

Received 4 March 2016; Accepted 4 May 2016

Academic Editor: Xian-He Bu

Copyright (c) 2016 S. Santha Lakshmi and K. Geetha. This is an open access article distributed under the Creative Commons Attribution License, which permits unrestricted use, distribution, and reproduction in any medium, provided the original work is properly cited.

\begin{abstract}
Ternary Schiff base copper(II) complex [CuL(tmpda)] (where $\mathrm{H}_{2} \mathrm{~L}$ is $\mathrm{N}$-(salicylidene)-L-valine; tmpda is $\mathrm{N}, \mathrm{N}, \mathrm{N}^{\prime}, \mathrm{N}^{\prime}$-tetramethyl1,3-propanediamine) has been characterized by UV-Vis., FTIR, and single crystal XRD. The crystal structure displays a distorted square pyramidal geometry in which Schiff base is bonded to the $\mathrm{Cu}(\mathrm{II})$ ion via phenolate oxygen, imine nitrogen, and an oxygen atom of the carboxylate group through the basal plane and the chelating diamine, $\mathrm{N}, \mathrm{N}, \mathrm{N}^{\prime}, \mathrm{N}^{\prime}$-tetramethyl-1,3-propanediamine, displays an axial and equatorial mode of binding via $\mathrm{NN}$-donor atoms.
\end{abstract}

\section{Introduction}

Transition metal complexes derived from Schiff bases have attracted attention of the researchers for their extensive application in the field of industry and biology [1]. The Schiff bases derived from amino acids and $o$-hydroxy aldehydes or ketones are found to be tridentate $[2,3]$. The metal complexes derived from $\mathrm{N}$-alkylidene or $\mathrm{N}$-arylidene alkanato have attracted much attention owing to their interest in several fields of biological systems, as well as due to their electrochemical properties. Schiff base amino acids are very good chelating agents. The transition metal complexes derived from salicylaldehyde and amino acids can serve as nonenzymatic models for the more complicated metalpyridoxal (vitamin B6) amino acid Schiff base systems and are the key intermediates for many metabolic reactions of amino acids catalyzed by enzymes $[4,5]$. Transition metal complexes derived from amino acid Schiff bases were reported to exhibit antimicrobial, antitumor, and antilarval activities and also act as mimetic systems of enzyme models [6-9].

Herein, we report the synthesis, crystal structure, and spectroscopic studies of Schiff base copper(II) complex derived from $\mathrm{N}$-(salicylidene)-L-valine and, an aliphatic chelating diamine, tmpda.

\section{Experimental}

2.1. Materials and Physical Measurements. All the reagents and chemicals were procured from commercial sources and were used without purification. Copper(II) acetate monohydrate, salicylaldehyde, and $\mathrm{N}, \mathrm{N}, \mathrm{N}^{\prime}, \mathrm{N}^{\prime}$-tetramethyl1,3-propanediamine were purchased from Sigma Aldrich.

Molar conductance of the complex was measured in DMF $\left(10^{-3} \mathrm{M}\right)$ using a direct digital conductometer. Elemental analyses of the $\mathrm{Cu}(\mathrm{II})$ complex were performed with a PerkinElmer model 2400 series II CHN analyzer. FTIR spectrum of solid complex was recorded using $\mathrm{KBr}$ pellet in the region of $4000-400 \mathrm{~cm}^{-1}$ on AVATAR 330 spectrophotometer. UVVisible spectrum of the complex in DMF was recorded in the region of $200-800 \mathrm{~nm}$ using a Hitachi U-2800 spectrophotometer.

2.2. Synthesis. The procedure for the synthesis of Schiff base copper(II) complex is given below and the structure of the Schiff base is depicted in Figure 1.

L-valine $(0.351 \mathrm{~g}, 3 \mathrm{mmol})$ and $\mathrm{KOH}(0.336 \mathrm{~g}, 6 \mathrm{mmol})$ were dissolved in water. To this an ethanolic solution $(25 \mathrm{~mL})$ of salicylaldehyde $(0.3 \mathrm{~mL}, 3 \mathrm{mmol})$ was added. The reaction mixture was stirred for about $1 \mathrm{~h}$ at $333 \mathrm{~K}$. The solution 


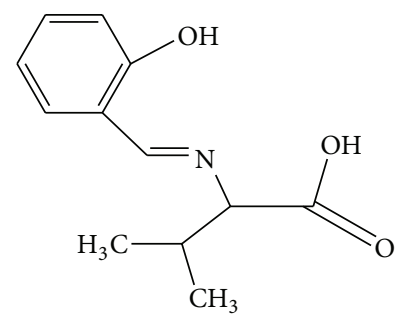

FIGURE 1: Structure of Schiff base ligand $\left(\mathrm{H}_{2} \mathrm{~L}\right)$.

turned yellow. To the above solution, copper(II) acetate monohydrate $(0.61 \mathrm{~g}, 3 \mathrm{mmol})$ was added and the reaction mixture was stirred for $1 \mathrm{~h}$, followed by addition of tmpda $(0.3 \mathrm{~mL}, 3 \mathrm{mmol})$. The mixture was stirred for another $2 \mathrm{~h}$ at the same temperature. The resultant green colored solution was filtered and kept at room temperature. Green colored crystals were obtained after the evaporation of the mother liquor. Finally, it was filtered and dried. below:

Analytical data of Schiff base Cu(II) complex are given

$$
\text { MF: } \mathrm{C}_{19} \mathrm{H}_{31} \mathrm{O}_{3} \mathrm{~N}_{3} \mathrm{Cu} ; \Lambda_{\mathrm{M}}=2.3 \Omega^{-1} \mathrm{~cm}^{2} \mathrm{~mol}^{-1} \text {; }
$$

Elemental analyses found (calculated) \%: C: 55.26 (55.25); H: 7.63 (7.57); N: 10.18 (10.17).

2.3. X-Ray Crystallography. Single crystal X-ray diffraction data of the Schiff base ternary copper(II) complex was used for data collected on a Bruker single crystal Kappa Apex II diffractometer. Single crystals of $\mathrm{Cu}$ (II) complex suitable for X-ray diffraction study were obtained from slow evaporation of the mother liquor at room temperature. A green colored crystal of the $\mathrm{Cu}$ (II) complex having the dimensions $0.13 \times 0.22 \times 0.25 \mathrm{~mm}$ was used for the $\mathrm{X}$-ray crystallographic analysis. Crystal data were collected using graphite monochromatized Mo-K $\alpha$ radiation $(\lambda=0.71073 \AA)$.

The structure of $\mathrm{Cu}(\mathrm{II})$ complex was solved by direct methods using SHELXS-97 and refined by full-matrix leastsquares techniques against $F^{2}$ using SHELXL-2014/7 [10, 11]. All the nonhydrogen atoms were refined anisotropically. A summary of pertinent crystal data along with further details of structure determination and refinement is given in Table 1.

\section{Results and Discussion}

3.1. Solubility. The $\mathrm{Cu}(\mathrm{II})$ complex was found to be freely soluble in DMSO, DMF, and ethanol at room temperature, whereas it is partially soluble in water and chloroform. The lower molar conductivity value $\left(2.3 \Omega^{-1} \mathrm{~cm}^{2} \mathrm{~mol}^{-1}\right)$ of the complex in DMF $\left(10^{-3} \mathrm{M}\right)$ indicated the nonelectrolytic nature [12].

3.2. Crystal Structure of [CuL(tmpda)]. The selected bond lengths and bond angles of the Schiff base $\mathrm{Cu}$ (II) complex are listed in Table 2. The $\mathrm{Cu}$ (II) complex crystallizes in the tetragonal system, with the space group $P 43$ and with the values $a=10.7750(6) \AA, b=10.7750(6) \AA$, and
TABLE 1: Crystal data and structure refinement for [CuL(tmpda)].

\begin{tabular}{|c|c|}
\hline CCDC deposition number & 1406394 \\
\hline Empirical formula & $\mathrm{C}_{19} \mathrm{H}_{31} \mathrm{CuN}_{3} \mathrm{O}_{3}$ \\
\hline Formula weight $(\mathrm{g} / \mathrm{mol})$ & 413.01 \\
\hline Temperature $(\mathrm{K})$ & $296(2)$ \\
\hline Wavelength $(\AA)$ & 0.71073 \\
\hline Crystal system, space group & Tetragonal, $P 43$ \\
\hline \multicolumn{2}{|l|}{ Unit cell dimensions } \\
\hline$a, b, c(\AA)$ & $\begin{array}{l}\text { 10.7750(6), 10.7750(6), } \\
17.8722(10)\end{array}$ \\
\hline$\alpha, \beta, \gamma\left(^{\circ}\right)$ & $90,90,90$ \\
\hline Volume $\left(\AA^{3}\right)$ & $2075.0(3)$ \\
\hline$Z$, calculated density $\left(\mathrm{g} / \mathrm{cm}^{3}\right)$ & $4,1.322$ \\
\hline Absorption coefficient $\left(\mathrm{mm}^{-1}\right)$ & 1.075 \\
\hline$F(000)$ & 876 \\
\hline Crystal size $(\mathrm{mm})$ & $0.130 \times 0.220 \times 0.250$ \\
\hline$\theta$ range for data collection $\left(^{\circ}\right)$ & 1.89 to 24.98 \\
\hline Limiting indices & $\begin{array}{l}-12 \leq h \leq 7,-10 \leq k \leq 12 \\
-20 \leq l \leq 21\end{array}$ \\
\hline Reflections collected/unique & $7583 / 4920$ \\
\hline Independent reflections & $3452[R($ int $)=0.0298]$ \\
\hline Completeness to theta $=25.00^{\circ}$ & $100 \%$ \\
\hline Absorption correction none $<41$ & Multiscan \\
\hline Max. and min. transmission & 0.8730 and 0.7750 \\
\hline Refinement method & $\begin{array}{l}\text { Full-matrix least-squares } \\
\text { on } F^{2}\end{array}$ \\
\hline Refinement program & $\begin{array}{l}\text { SHELXL-2014/7 (Sheldrick, } \\
\text { 2014) }\end{array}$ \\
\hline Function minimized & $\Sigma w\left(F_{o}^{2}-F_{c}^{2}\right)^{2}$ \\
\hline Data/restraints/parameters & $3452 / 1 / 241$ \\
\hline Goodness of fit on $F^{2}$ & 1.026 \\
\hline$\Delta / \sigma_{\max }$ & 0.073 \\
\hline Final $R$ indices $[I>2 \sigma(I)]$ & $R 1=0.0529, w R 2=0.1290$ \\
\hline$R$ indices (all data) & $R 1=0.0640, w R 2=0.1361$ \\
\hline Absolute structure parameter & $1.0(0)$ \\
\hline Largest diff. peak and hole $\left(\mathrm{e} \cdot \AA^{-3}\right)$ & 0.307 and -0.280 \\
\hline RMS deviation from mean & $0.053 \mathrm{e}^{-3}$ \\
\hline
\end{tabular}

$c=17.8722(10) \AA, \alpha=90^{\circ}, \beta=90^{\circ}$, and $\gamma=90^{\circ}, V=$ 2075.0(3) $\AA^{3}$, and $Z=4$. An ORTEP view of copper(II) complex along with the atom numbering scheme is shown in Figure 2.

Five coordinated $\mathrm{Cu}(\mathrm{II})$ complexes exist with square pyramidal ( $\mathrm{sp}$ ) or trigonal bipyramidal (tbp) geometry. In order to distinguish between $\mathrm{sp}$ and tbp geometries in case of five coordinated complexes, Addison et al. [13] introduced trigonality index $\tau$ (where $\tau=(\beta-\alpha) / 60$, in which $\alpha$ and $\beta$ are the two largest coordination angles). In general, for an ideal square pyramidal $\tau=0$ and for ideal tbp geometry, $\tau=1$. In the present case, taking the angles $\mathrm{N}(3)-\mathrm{Cu}(1)-$ $\mathrm{N}(2) 167.0^{\circ}$ as $\alpha$ and $\mathrm{O}(1)-\mathrm{Cu}(1)-\mathrm{O}(2) 171.9^{\circ}$ as $\beta$, the $\tau$ value is calculated. For $\mathrm{Cu}(\mathrm{II})$ complex the $\tau$ value is 0.0816 , 
TABLE 2: Selected bond lengths $(\AA)$ and angles $\left({ }^{\circ}\right)$ for the [CuL(tmpda)].

\begin{tabular}{llll}
\hline $\mathrm{Cu}(1)-\mathrm{O}(1)$ & $1.923(6)$ & $\mathrm{O}(1)-\mathrm{Cu}(1)-\mathrm{N}(3)$ & $92.1(3)$ \\
$\mathrm{Cu}(1)-\mathrm{O}(2)$ & $1.959(6)$ & $\mathrm{N}(3)-\mathrm{Cu}(1)-\mathrm{O}(2)$ & $83.0(3)$ \\
$\mathrm{Cu}(1)-\mathrm{N}(1)$ & $2.445(8)$ & $\mathrm{N}(3)-\mathrm{Cu}(1)-\mathrm{N}(2)$ & $167.0(3)$ \\
$\mathrm{Cu}(1)-\mathrm{N}(3)$ & $1.954(7)$ & $\mathrm{O}(1)-\mathrm{Cu}(1)-\mathrm{N}(1)$ & $95.4(3)$ \\
$\mathrm{Cu}(1)-\mathrm{N}(2)$ & $2.058(7)$ & $\mathrm{O}(2)-\mathrm{Cu}(1)-\mathrm{N}(1)$ & $91.9(3)$ \\
& & $\mathrm{O}(1)-\mathrm{Cu}(1)-\mathrm{O}(2)$ & $171.9(3)$ \\
& & $\mathrm{O}(1)-\mathrm{Cu}(1)-\mathrm{N}(2)$ & $89.3(3)$ \\
& & $\mathrm{O}(2)-\mathrm{Cu}(1)-\mathrm{N}(2)$ & $94.1(3)$ \\
& & $\mathrm{N}(3)-\mathrm{Cu}(1)-\mathrm{N}(1)$ & $100.6(3)$ \\
& & $\mathrm{N}(2)-\mathrm{Cu}(1)-\mathrm{N}(1)$ & $92.2(3)$ \\
\hline
\end{tabular}

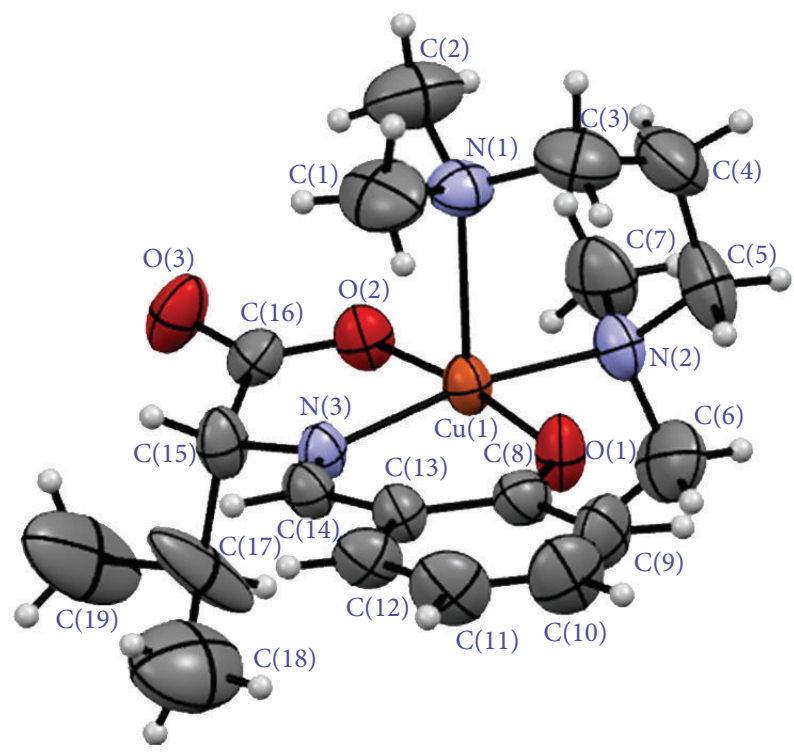

FIgURE 2: An ORTEP view of [CuL(tmpda)] along with the numbering scheme.

which indicates nearly an ideal square pyramidal geometry around $\mathrm{Cu}(\mathrm{II})$ ion. The basal plane is occupied by imine nitrogen atom $\mathrm{N}(3)$, phenolate oxygen atom $\mathrm{O}(1)$, and one of the oxygen atoms $\mathrm{O}(2)$ of carboxylate group of Schiff base and one of the nitrogen atoms $\mathrm{N}(2)$. The axial site is occupied by another nitrogen atom $\mathrm{N}(1)$ of tmpda. The $\mathrm{Cu}(1)-\mathrm{N}(3), \mathrm{Cu}(1)-\mathrm{N}(2), \mathrm{Cu}(1)-\mathrm{O}(1)$, and $\mathrm{Cu}(1)-\mathrm{O}(2)$ distances are 1.954(7) $\AA, 2.058(7) \AA, 1.923(6) \AA$, and 1.959(6) $\AA$, respectively, and the $\mathrm{Cu}(1)-\mathrm{N}(1)$ bond length $2.445(8) \AA$ is significantly longer than the equatorial bonds.

The equatorial $\mathrm{O}(1)-\mathrm{Cu}(1)-\mathrm{N}(3), \quad \mathrm{N}(3)-\mathrm{Cu}(1)-\mathrm{O}(2)$, $\mathrm{O}(2)-\mathrm{Cu}(1)-\mathrm{N}(2)$, and $\mathrm{O}(1)-\mathrm{Cu}(1)-\mathrm{N}(2)$ bond angles are 92.1(3) ${ }^{\circ}, 83.0(3)^{\circ}, 94.1(3)^{\circ}$, and $89.3(3)^{\circ}$, respectively. The sum of the angles around copper(II) ion is $358.5^{\circ}$, close to $360^{\circ}$. Hence, the atoms $\mathrm{O}(1), \mathrm{O}(2), \mathrm{N}(3), \mathrm{N}(2)$, and $\mathrm{Cu}(1)$ lie in one plane with the slight deviation of copper(II) ion from the basal plane. The apical $\mathrm{N}(2)-\mathrm{Cu}(1)-\mathrm{N}(1)$, $\mathrm{N}(3)-\mathrm{Cu}(1)-\mathrm{N}(1), \mathrm{O}(1)-\mathrm{Cu}(1)-\mathrm{N}(1)$, and $\mathrm{O}(2)-\mathrm{Cu}(1)-\mathrm{N}(1)$ bond angles are $92.2(3)^{\circ}, 100.6(3)^{\circ}, 95.4(3)^{\circ}$, and 91.9(3)

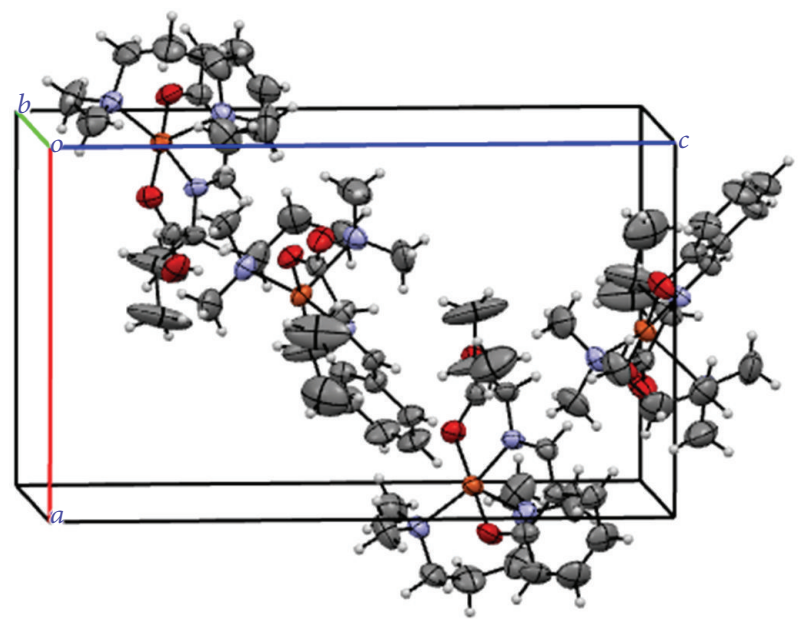

FIGURE 3: The unit cell packing diagram of the [CuL(tmpda)] viewed along $b$-axis.

respectively. The diagonal bond angles for $\mathrm{O}(1)-\mathrm{Cu}(1)-\mathrm{O}(2)$ and $\mathrm{N}(3)-\mathrm{Cu}(1)-\mathrm{N}(2)$ are $171.9(3)^{\circ}$ and $167.0(3)^{\circ}$, respectively.

3.3. Crystal Packing. The crystal packing of the $\mathrm{Cu}(\mathrm{II})$ complex is shown in Figure 3. No notable hydrogen bonding was found and van der Waals force is the main intermolecular interaction. The two-dimensional chain formed by van der Waals forces between hydrogen atoms ( $\mathrm{H} 14$ and H5A) and the noncoordinated carboxylate oxygen atoms $(\mathrm{O}(3))$ of the Schiff bases [14] ligand.

FTIR spectrum of [CuL(tmpda)] exhibited an intense band at $1627 \mathrm{~cm}^{-1}$, corresponding to a coordinated imine group with $\mathrm{Cu}$ (II) ion. The band appeared at $1284 \mathrm{~cm}^{-1}$, indicating the coordination of the Schiff base ligand with the copper(II) ion, via deprotonation. The asymmetric $\left(v_{\mathrm{as}} \mathrm{COO}^{-}\right)$and symmetric stretching were observed at 1533 and $1340 \mathrm{~cm}^{-1}$, respectively. The separation between asymmetric and symmetric bands $\Delta v=\left[v_{\mathrm{as}} \mathrm{COO}^{-}-v_{\mathrm{s}} \mathrm{COO}^{-}\right]$of the complex is greater than that of free carboxylate anion $\left(145 \mathrm{~cm}^{-1}\right)$. This confirms the monodentate coordination of the carboxylate ion present in the Schiff base ligand [15]. The appearance of bands at 466 and $557 \mathrm{~cm}^{-1}$ is assigned to $v(\mathrm{Cu}-$ $\mathrm{O})$ and $v(\mathrm{Cu}-\mathrm{N})$, respectively [16].

The electronic absorption spectrum of $\mathrm{Cu}(\mathrm{II})$ recorded in DMF $\left(10^{-3} \mathrm{M}\right)$ showed an absorption band at $280 \mathrm{~nm}$ and $365 \mathrm{~nm}$ can be assigned to $\pi-\pi^{*}$ transition of aromatic chromophore and $\mathrm{n}-\pi^{*}$ transition of imine moiety, respectively. A broad band observed at $650 \mathrm{~nm}$ corresponds to d-d transition.

\section{Conclusion}

A ternary Schiff base copper(II) complex [CuL(tmpda)] was synthesized and characterized by UV-Vis. and FTIR spectroscopy. The structure of the complex was unambiguously studied by single crystal XRD. Molar conductance measurement confirmed the nonelectrolytic nature of the complex. 
The XRD studies revealed square pyramidal geometry for the complex. $\mathrm{Cu}$ (II) ion was coordinated via phenolic oxygen, imine nitrogen, and oxygen atom of carboxylate group of Schiff base ligand occupying the basal plane, whereas nitrogen atoms of tmpda occupy axial as well as equatorial sites.

\section{Competing Interests}

The authors declare that there are no competing interests regarding the publication of this paper.

\section{Acknowledgments}

The financial support of this work by University Grants Commission, India (MRP-5199/14 (UGC-SERO)), is gratefully acknowledged.

\section{References}

[1] M. Z. Wang, G. L. Cai, L. Xia et al., "Crystal structures of two potential tumor imaging agents and therapeutic agents-copper (II) ternary complexes with salicylidene-tyrosinato Schiff base and nitrogen-donor chelating Lewis base," Chinese Chemical Letters, vol. 15, no. 4, pp. 495-497, 2004.

[2] Y.-J. Yan, F. Yin, J. Chen et al., "Supramolecular copper(II) complexes of novel Schiff bases derived from $\beta$-amino acid and salicylaldehyde: syntheses, crystal structure, and magnetic property," Inorganica Chimica Acta, vol. 413, pp. 84-89, 2014.

[3] A. Li, Y.-H. Liu, L.-Z. Yuan et al., "Association of structural modifications with bioactivity in three new copper(II) complexes of Schiff base ligands derived from 5-chlorosalicylaldehyde and amino acids," Journal of Inorganic Biochemistry, vol. 146, article 9674, pp. 52-60, 2015.

[4] Á. García-Raso, J. J. Fiol, F. Bádenas, and F. Muoz, "Bioinorganic chemistry of copper(II) complexes of N-salicylideneaminoacidato: Associative versus dissociative mechanism in the formation of copper ternary complexes with 2-aminopyridine (or pyrimidine). An ab initio study," Polyhedron, vol. 20, no. 20, pp. 2609-2618, 2001.

[5] L. Casella and M. Gullotti, "Synthesis, stereochemistry, and oxygenation of cobalt(II)-pyridoxal model complexes. A new family of chiral dioxygen carriers," Inorganic Chemistry, vol. 25, no. 9, pp. 1293-1303, 1986.

[6] Ö. Özdemir (nee Güngör), P. Gürkan, B. Özçelik, and Ö. Oyard1, "Synthesis and antimicrobial activities of new higher amino acid Schiff base derivatives of 6-aminopenicillanic acid and 7-aminocephalosporanic acid," Journal of Molecular Structure, vol. 1106, pp. 181-191, 2016.

[7] T. Ma, J. Xu, Y. Wang et al., “Ternary copper(II) complexes with amino acid chains and heterocyclic bases: DNA binding, cytotoxic and cell apoptosis induction properties," Journal of Inorganic Biochemistry, vol. 144, pp. 38-46, 2015.

[8] W. Zishen, G. Ziqi, and Y. Zhenhuan, "Synthesis, characterization and anticancer activity of L-alanine Schiff base complexes of copper(II), zinc(II), nickel(II) and cobalt(II)," Synthesis and Reactivity in Inorganic and Metal-Organic Chemistry, vol. 20, no. 3, pp. 335-344, 1990.

[9] P. A. N. Reddy, M. Nethaji, and A. R. Chakravarty, "Hydrolytic cleavage of DNA by ternary amino acid Schiff base copper(II) complexes having planar heterocyclic ligands," European Journal of Inorganic Chemistry, vol. 2004, no. 7, pp. 1440-1446, 2004.

[10] G. M. Sheldrick, SHELXS-97: Program for the Crystal Structure Refinement, University of Göttingen, Göttingen, Germany, 2008.

[11] G. M. Sheldrick, SHELXL-2014/7: Program for the Solution of Crystal Structures, University of Göttingen, Göttingen, Germany, 2014.

[12] W. J. Geary, "The use of conductivity measurements in organic solvents for the characterisation of coordination compounds," Coordination Chemistry Reviews, vol. 7, no. 1, pp. 81-122, 1971.

[13] A. W. Addison, T. N. Rao, J. Reedijk, J. Van Rijn, and G. C. Verschoor, "Synthesis, structure, and spectroscopic properties of copper(II) compounds containing nitrogen-sulphur donor ligands; the crystal and molecular structure of aqua[1,7-bis $(N$ methylbenzimidazol-2';-yl)-2,6-dithiaheptane]copper(II) perchlorate," Journal of the Chemical Society, Dalton Transactions, no. 7, pp. 1349-1356, 1984.

[14] C. S. Hawes and P. E. Kruger, "Dimensionality variation in dinuclear $\mathrm{Cu}$ (II) complexes of a heterotritopic pyrazolate ligand," Crystals, vol. 4, no. 1, pp. 32-41, 2014.

[15] P. M. Reddy, A. V. S. S. Prasad, K. Shanker, and V. Ravinder, "Synthesis, spectral studies and antibacterial activity of novel macrocyclic Co(II) compounds," Spectrochimica Acta A, vol. 68, no. 3, pp. 1000-1006, 2007.

[16] K. Nakamoto, Infrared and Raman Spectra of Inorganic and Coordination Compounds, Wiley, New York, NY, USA, 1978. 

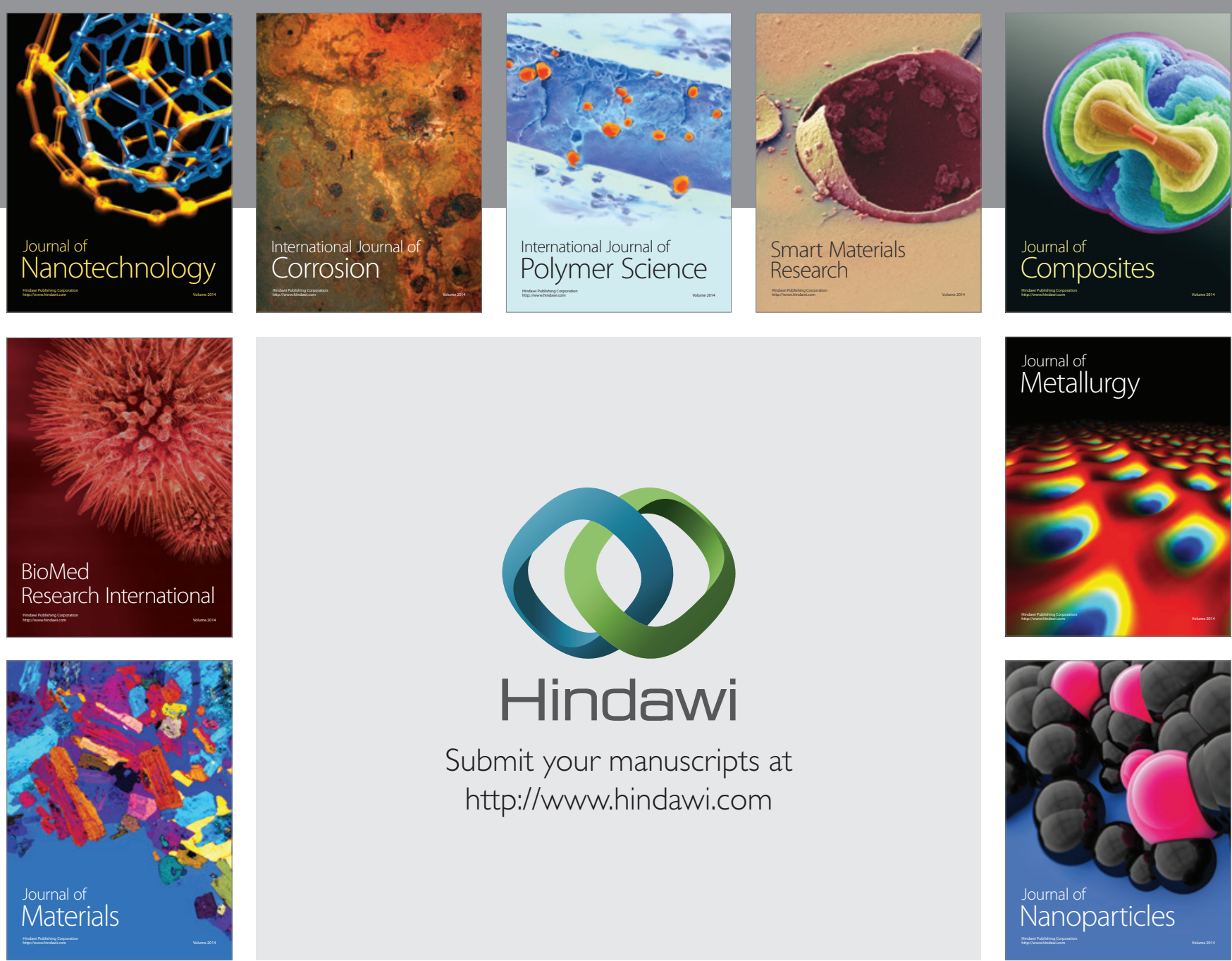

\section{Hindawi}

Submit your manuscripts at

http://www.hindawi.com

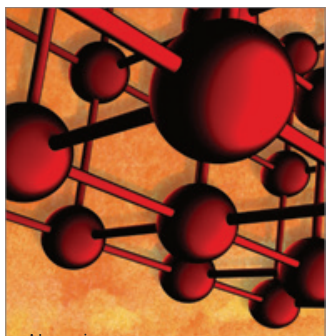

Materials Science and Engineering
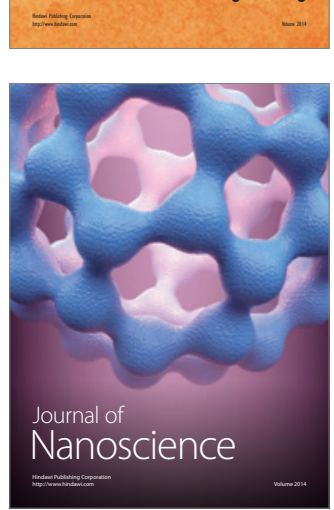
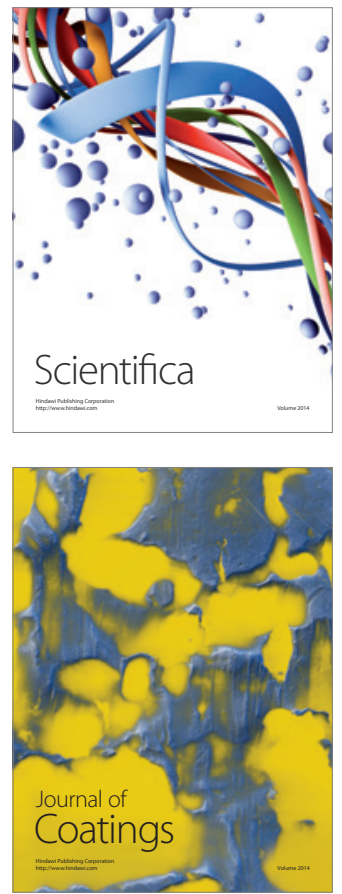
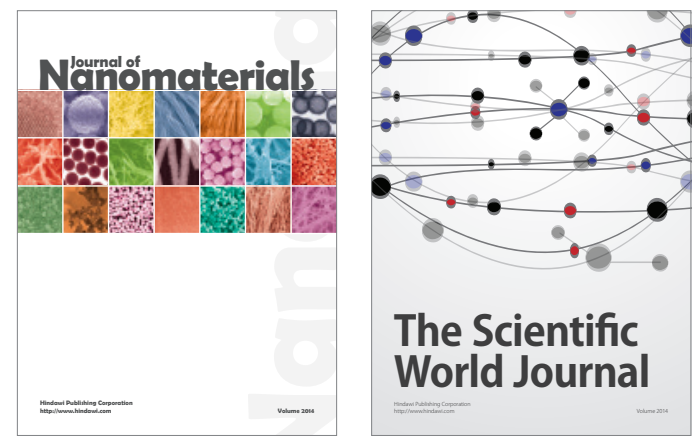

The Scientific World Journal
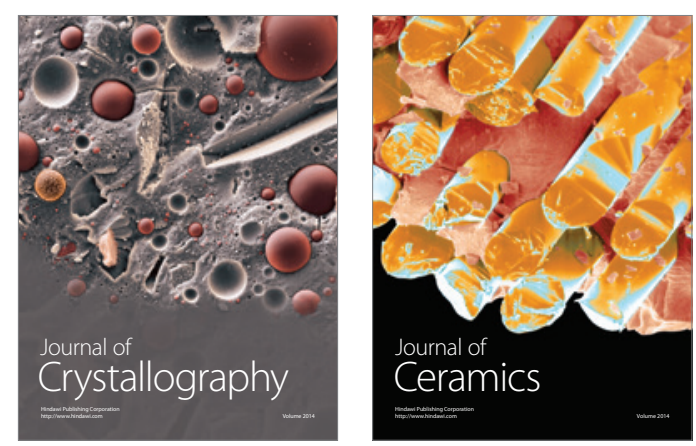
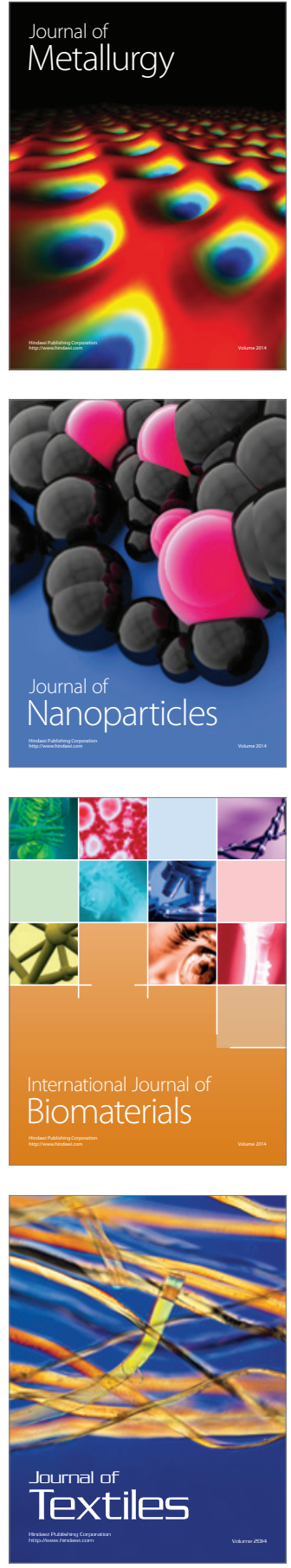